\title{
A Comparative Study of the Factors Contributing to Excellence in Government and Non-Government Primary Schools Of Kanpur Mandal.
}

\author{
Ashok Kumar \\ Assistant Professor, Dept. Of B.Ed, Dr.G.P.R.D.P.M/V Araul, Kanpur Nagar
}

\begin{abstract}
The topic for present study is A Comparative Study of the Factors Contributing to Excellence in Government and Non-Government Primary Schools of Kanpur Mandal .In which 120 excellent government primary schools and 120 excellent non-government primary schools are selected from rural \& urban areas and comparing 240 excellent primary schools. The data from these schools is collected from 2500 respondents by the help of self-constricted Questionnaire, Opinionnaire and data collection tool. For the analysis of data Critical Ratio (CR) \& Chi-squire,Mean, S.D.is being used. On the basis of data analysis, the researcher found following conclusions-(1)-Fundamental facilities, Teacher-taught ratio, Qualitative planning's, Sports facilities, Examination results, Educational environment, Indifferent environment regarding students, Language \& Mathematical development, All-round development, Student attendance and No of working dyes of nongovernment primary schools are found superior to government primary schools. (2)-Teacher qualifications, Student enrollment (Blow poverty line), Obstacles besides teaching work; of government primary schools are found superior to non-government primary schools. The findings or concluding's of the study will provide help to guardian's to select superior schools, to education officers to organize primary schools \& to provide then recognition, to help Research scholar's.
\end{abstract}

\section{Introduction}

In present time several types of schools on primary level are running in Kanpur division ,but their superiority level, specialty and characteristic is not same. It depends on their quality. Some schools out of them got special name /popularity \& fame, some specific characteristics or traits are found in these schools which attract people towards them. So along with the development of universal education, it is essential to comparative study on factors contributing excellence to primary schools. The present study needs -"A comparative study of the factors contributing to excellence in Government and Non- Government primary schools of KanpurMandal."

(a) Primary level-

\section{Definitionofimportantterms}

The school level in which students of 6-14 years age group do study.Primary and upper- primary schools are called primary level.

(b) Government \& Non-Government Primary Schools-

The government primary schools organized by government, but any primary school organized by individually called Non- government schools.

(c) Excellence-

Specific characteristicsof schools are called excellence.

(d) Factors contributing Excellence-

The factors which make any person, thing, idea or ideal -excellent are called factors contributing excellence.

\section{Reviewofrelatedliterature}

There are several studies conducted at primary stage in India.Findings of these studies are presented below -

Desai, D.M.(1951), conducted a study on " Compulsory Primary Education in India”.Ph.D. Education, Bombay University. The findings revealed that -

1-law of compulsory primary education could not effective on below the poverty linechildren.

2-Many problems in education studies are related to educational administration i.e. Enrolment, Single Teacher, School and supervision related. 
3-The effective implementation of compulsory primary education could not success because, lack of finance, changemeant in Report of Hartangecommittee, attitude of state government.

Tiwari, D.D. (1964) , "Primary Education in Uttar Pradesh" Ph.D. Education Allahabad University.The studies were carried out with an objective to comparative study of organization of primary education and educational administration in the present state organization. The major findings of the studies were-

1-Categories the primary school in the basis of administration and control.

2- Teachers economic level below in compression of other state and countries.

3-The progress of primary education were affected through government grant and low grant policy.

4-There were many problems in student enrolment in primary education.

Acharya,A.D.(1984), studies on " Compulsory primary education in Andhra Pradesh"A policy analysis. Ph.D. Education OSM,University.” The major findings were;

1-Therecould not implements any long time planning for general and primary education.

2-Compulsory education for 6-14 years children and mid- day meal plan was good in the area of education.

3-Only one exceptional school present for physically and mental disabled children in Berangal district.

Krishnamurty,R. (1985), "A study of the position of enrolment of children in the age group 6-14 years and problems involved in their enrolment". Major findings were;

1-There were $50 \%$ enrolment used sample for $6-11$ years children, like this $62 \%$ enrolment of children in the age group 11-14 years .

2 -There were $47 \%$ children of SC and $51 \%$ children of ST cast enrolled.

3 -Girls enrolment was very poor in elementary education.

Aggrawal ,Yash. (2001). "Progress towards universal access and retention .New Delhi: National Institute of Educational Planning and Administration."

The present study examined the various dimensions of access and retention in DPEP, and specifically focused on the structure and trends in enrolment for DPEP districts. The pupil -Teacher ratio has shown erratic behavior. Despite considerable progress in enrolment and retention. The study found that significant gains in access and retention have been made both under the formal as well as alternative systems of primary education.

Yadappanavar, A.V. (2002). "Factors influencing elementary schools"

The study revealed that poverty was the main reason for children not being able to attend school. Teachers faced the problem of the student population migrating along with their parents looking for jobs. Girls education was not given importance as compared to boys. Infrastructure facilities including toilet ,drinking water,playground,were not satisfactory.

Singh, Y.P, Joshi A and Garia, P.S. (2003)."Social acceptability of parishadiya primary schools in comparison with other type of schools functioning in the same area.Lucknow". The major findings were ;

1-The infrastructure facilities in private schools were in better condition compared to parishad schools with respect to availability of playgrounds and play materials and all were in pucca buildings.

2-Children have to pay high fees in private schools.

3-Parents were impressed with the quality of education and proper management in private schools.

Sud, Anup and Sujata. (2006). "Academic performance in relation to self -handicapping, test anxiety and study habits of high school children .Shimla" : Himanchal Pradesh University. The major findings were:

1-It was observed that males were willing to make ability attributions and were less confident of their ability with regards to test anxiety and its worry and emotionality components.

2-It was found that females experience more worry than their male counterparts.

Mehta, Arun, C. (2008). "Elementary education in India: analytical report 2006-07": New Delhi: NUEPA. The project covers both primary and upper primary schools of all the districts of the country. The major findings were:

1-More than $85 \%$ schools had drinking water facility.

2-The development may help in attracting more physically challenged children to schools.

3-About 1.42 million disabled children were enrolled in elementary classes across the country. 
IV. Importanceofthestudy

Primary education occupies an important role in the life of an individual. It is the base on which further educational opportunities of a child depends. The process of primary education is an index of the general, social and economic development of the country as a whole. Primary education plays an important role in laying the proper foundation of child's cultural, emotional, intellectual, moral, physical, social and spiritual development .So ideaof researchers, all primary level school shall be excellence in quality education, because primary education is the basis of child development.

\section{Objectives-}

To compare the factors contributing to excellence in the schools of government and non-government schools situated in Urban and Rural areas.

\section{Hypotheses-}

1. That there is no difference between the factors contributing to excellence of the urban government and Urban non-government primary schools.

2. That there is no difference between the factors contributing to excellence of the rural government and ruralnon-government primary schools.

\section{Delimitations-}

The study is confined to the primary schools of Kanpur Region. The first reason for delimiting the study to only excellent schools more effect on educated population. The study is limited to only primary schoolsof the Kanpur Region.

\section{(a) Research method-}

\section{Methodology}

Idealistic Survey method of research was employed for the present study.

\section{(b) Sample of the study-}

The sample consists of 240 primary schools from Urban and Rural areas in Kanpur Region and the 2500 teacher, educators, parents, students and others, from various schools, village and district education officers.

\section{(c) Variables in the study-}

The factors contributing to excellence in primary schools ( independent variable) and primary schools excellency ( dependent variable) were selected as variables in the study .

\section{(d) Tool used-}

The researcher was developed questionnaire, openionnaire and data collection tool.

\section{(e) Data collection method-}

Data collection was done by personally contacting the respondent as well as copies of the questionnaire, openionnaire and data collection tool distributed physically to the respondent. Some of the respondent were contacted again physically or through phone and argued to complete the data collection tool.

\section{(f) Analysis of Data-}

Obtained data were analyzed with the help of Mean and S.D. In addition to their critical ratio ( C.R.) and Chi- squire also used for examining significant difference between two different groups.

Table 1Mean,S.D. and C.R Value of Factors Contributing to Excellence Score of Urban government and Urban Non-government Primary Schools.

\begin{tabular}{|c|c|c|c|c|c|c|}
\hline $\begin{array}{l}\text { Factors } \\
\text { Contributing to } \\
\text { excellence }\end{array}$ & $\mathbf{N}$ & Mean & S.D. & $\begin{array}{l}\text { Mean } \\
\text { Difference }\end{array}$ & D.f. & C.R. \\
\hline \multirow[t]{2}{*}{$\begin{array}{l}\text { Fundament } \\
\text { Facilities }\end{array}$} & 250 & 4.728 & 1.268 & \multirow[t]{2}{*}{1.407} & \multirow[t]{2}{*}{498} & 15.938 \\
\hline & 250 & 6.656 & 1.432 & & & $* *$ \\
\hline \multirow{2}{*}{$\begin{array}{l}\text { Students } \\
\text { Enrolment } \\
\text { (BlowPoverty } \\
\text { Line) }\end{array}$} & 250 & 1.996 & 0.807 & \multirow[t]{2}{*}{1.026} & \multirow[t]{2}{*}{498} & 14.591 \\
\hline & 250 & 1.068 & 0.600 & & & $* *$ \\
\hline
\end{tabular}


A Comparative Study of the Factors Contributing to Excellence in Government and Non.....

\begin{tabular}{|c|c|c|c|c|c|c|}
\hline \multirow[t]{2}{*}{$\begin{array}{l}\text { Teacher, Student } \\
\text { Ratio }\end{array}$} & 250 & 0.240 & 0.296 & \multirow[t]{2}{*}{0.484} & \multirow[t]{2}{*}{498} & \multirow{2}{*}{$\begin{array}{l}14.188 \\
* *\end{array}$} \\
\hline & 250 & 0.756 & 0.493 & & & \\
\hline \multirow{2}{*}{$\begin{array}{l}\text { Abstracters } \\
\text { besides } \\
\text { Teaching work }\end{array}$} & 250 & 5.472 & 1.303 & \multirow[b]{2}{*}{4.422} & \multirow[b]{2}{*}{498} & \multirow[b]{2}{*}{$\begin{array}{l}32.415 \\
* *\end{array}$} \\
\hline & 250 & 10.18 & 1.891 & & & \\
\hline \multirow{2}{*}{$\begin{array}{l}\text { Teachers } \\
\text { qualification }\end{array}$} & 250 & 0.740 & 0.493 & \multirow[b]{2}{*}{0.392} & \multirow[b]{2}{*}{498} & \multirow[b]{2}{*}{$\begin{array}{l}\mathbf{1 0 . 5 1 5} \\
* *\end{array}$} \\
\hline & 250 & 0.344 & 0.334 & & & \\
\hline \multirow{2}{*}{$\begin{array}{l}\text { Qualitative } \\
\text { Planning's for } \\
\text { students }\end{array}$} & 250 & 3.304 & 1.080 & \multirow[t]{2}{*}{2.212} & \multirow[t]{2}{*}{498} & \multirow{2}{*}{$\begin{array}{l}\mathbf{5 5 . 2 0 7} \\
* *\end{array}$} \\
\hline & 250 & 9.014 & 1.228 & & & \\
\hline \multirow[t]{2}{*}{ Sports Facilities } & 250 & 1.936 & 0.792 & \multirow[b]{2}{*}{2.336} & \multirow[b]{2}{*}{498} & \multirow[b]{2}{*}{$\begin{array}{l}26.493 \\
* * \\
* *\end{array}$} \\
\hline & 250 & 4.424 & 1.256 & & & \\
\hline \multirow[t]{2}{*}{ Results } & 250 & 0.564 & 0.119 & \multirow[b]{2}{*}{0.348} & \multirow[b]{2}{*}{498} & \multirow[b]{2}{*}{$\begin{array}{l}8.219 \\
* *\end{array}$} \\
\hline & 250 & 0.916 & 0.532 & & & \\
\hline \multirow[t]{2}{*}{$\begin{array}{l}\text { Educational } \\
\text { Environment }\end{array}$} & 250 & 0.496 & 0.400 & \multirow[t]{2}{*}{1.194} & \multirow[t]{2}{*}{498} & \multirow{2}{*}{$\begin{array}{l}16.483 \\
* *\end{array}$} \\
\hline & 250 & 1.712 & 0.742 & & & \\
\hline \multirow{2}{*}{$\begin{array}{l}\text { Language \& } \\
\text { Mathematical } \\
\text { Development }\end{array}$} & 250 & 0.972 & 0.565 & \multirow[t]{2}{*}{0.604} & \multirow[t]{2}{*}{498} & \multirow{2}{*}{$\begin{array}{l}11.597 \\
* *\end{array}$} \\
\hline & 250 & 1.588 & 0.622 & & & \\
\hline \multirow[t]{2}{*}{$\begin{array}{l}\text { All round } \\
\text { Development }\end{array}$} & 250 & 3.108 & 1.001 & \multirow[t]{2}{*}{1.848} & \multirow[t]{2}{*}{498} & 19.740 \\
\hline & 250 & 5.120 & 1.263 & & & $* *$ \\
\hline $\begin{array}{l}\text { Indifferent } \\
\text { Environment }\end{array}$ & 250 & 3.848 & 1.126 & 0.506 & 498 & 4.040 \\
\hline $\begin{array}{l}\text { regarding } \\
\text { Students }\end{array}$ & 250 & 3.460 & 1.019 & & & $* *$ \\
\hline $\begin{array}{l}\text { Students } \\
\text { Attendance }\end{array}$ & 120 & 81.68 & 5.162 & 12.05 & 118 & 12.602 \\
\hline & 120 & 93.96 & 5.507 & & & $* *$ \\
\hline
\end{tabular}

$* *$-Significant on 0.05 and 0.01 levels ofsignificant.

Table $\mathbf{- 1}$ shows that there is significant difference between the factors contributing to excellence of urban government and urban non-government primary schools of Students enrolment and teachers qualifications, because C.R .value is significant at 0.05 levels. Since the mean score of urban government schools is higher, so it is clear that urban government schools had higher in the student's enrolment and teachers qualifications factors.

Table -1 also shows that there is significant difference between the factors contributing to excellence of urban government and urban non- government primary schools of fundamental facilities ,teacher student ratio, abstracters besides teaching work, qualitative planning's for students, sports facilities, results, educational environment, language and mathematical development, all round development of students, indifferent environment regarding students, students attendance, because C.R. value is significant at 0.05 level. Since the mean score of urban non-government school had higher in these factors.

Table 2Mean,S.D. and C.R Value of Factors Contributing to Excellence Score of Rural government and Rural Non-government Primary Schools.

\begin{tabular}{|c|c|c|c|c|c|c|}
\hline $\begin{array}{l}\text { Factors } \\
\text { Contributing to } \\
\text { excellence }\end{array}$ & $\mathbf{N}$ & Mean & S.D. & $\begin{array}{l}\text { Mean } \\
\text { Difference }\end{array}$ & D .f. & C.R. \\
\hline \multirow{2}{*}{$\begin{array}{l}\text { Fundament } \\
\text { Facilities }\end{array}$} & 250 & 4.352 & 1.118 & \multirow[b]{2}{*}{1.524} & \multirow[b]{2}{*}{498} & \multirow{2}{*}{$\begin{array}{l}13.603 \\
* *\end{array}$} \\
\hline & 250 & 5.876 & 1.374 & & & \\
\hline \multirow{3}{*}{$\begin{array}{l}\text { Students } \\
\text { Enrolment } \\
\text { (Blow Poverty } \\
\text { Line) }\end{array}$} & 250 & 1.996 & 0.800 & \multirow{3}{*}{1.128} & \multirow{3}{*}{498} & \multirow{3}{*}{$\begin{array}{l}\mathbf{1 8 . 5 3 0} \\
* *\end{array}$} \\
\hline & & & & & & \\
\hline & 250 & 0.872 & 0.529 & & & \\
\hline
\end{tabular}


A Comparative Study of the Factors Contributing to Excellence in Government and Non.....

\begin{tabular}{|c|c|c|c|c|c|c|}
\hline \multirow[t]{2}{*}{$\begin{array}{l}\text { Teacher, Student } \\
\text { Ratio }\end{array}$} & 250 & 0.232 & 0.282 & \multirow{2}{*}{0.448} & \multirow{2}{*}{498} & \multirow[t]{2}{*}{$\begin{array}{l}12.626 \\
* *\end{array}$} \\
\hline & 250 & 0.680 & 0.485 & & & \\
\hline \multirow{2}{*}{$\begin{array}{l}\text { Abstracters } \\
\text { besides Teaching } \\
\text { work }\end{array}$} & 250 & 4.988 & 1.283 & \multirow[b]{2}{*}{4.160} & \multirow[b]{2}{*}{498} & \multirow{2}{*}{$\begin{array}{l}\text { 30.01 } \\
* *\end{array}$} \\
\hline & 250 & 9.148 & 1.777 & & & \\
\hline \multirow{3}{*}{$\begin{array}{l}\text { Teachers } \\
\text { qualification }\end{array}$} & 250 & 0.660 & 0.481 & \multirow{3}{*}{0.388} & \multirow{3}{*}{498} & \multirow{3}{*}{$\underset{* *}{10.862}$} \\
\hline & & & & & & \\
\hline & 250 & 2.272 & 0.296 & & & \\
\hline \multirow{2}{*}{$\begin{array}{l}\text { Qualitative } \\
\text { Planning's for } \\
\text { students }\end{array}$} & 250 & 3.088 & 1.009 & \multirow[b]{2}{*}{2.056} & \multirow[b]{2}{*}{498} & \multirow[b]{2}{*}{$\begin{array}{l}19.897 \\
* *\end{array}$} \\
\hline & 250 & 5.144 & 1.285 & & & \\
\hline \multirow[t]{3}{*}{ Sports Facilities } & 250 & 2.076 & 0.869 & \multirow{3}{*}{1.880} & \multirow{3}{*}{498} & \multirow{3}{*}{$\underset{* *}{21.205}$} \\
\hline & & & & & & \\
\hline & 250 & 3.956 & 1.100 & & & \\
\hline \multirow[t]{2}{*}{ Results } & 250 & 0.520 & 0.414 & \multirow[b]{2}{*}{0.345} & \multirow[b]{2}{*}{498} & \multirow{2}{*}{$\begin{array}{l}\mathbf{8 . 1 3 5} \\
* *\end{array}$} \\
\hline & 250 & 0.864 & 0.525 & & & \\
\hline \multirow{3}{*}{$\begin{array}{l}\text { Educational } \\
\text { Environment }\end{array}$} & 250 & 0.444 & 0.374 & \multirow{3}{*}{1.172} & \multirow{3}{*}{498} & \multirow{3}{*}{$\begin{array}{l}22.422 \\
* *\end{array}$} \\
\hline & & & & & & \\
\hline & 250 & 1.616 & 0.737 & & & \\
\hline \multirow{2}{*}{$\begin{array}{l}\text { Language \& } \\
\text { Mathematical } \\
\text { Development }\end{array}$} & 250 & 0.836 & 0.501 & \multirow[b]{2}{*}{0.592} & \multirow[b]{2}{*}{498} & \multirow{2}{*}{$\begin{array}{l}11.040 \\
* *\end{array}$} \\
\hline & 250 & 1.428 & 0.684 & & & \\
\hline All round & 250 & 2.852 & 0.959 & & & \\
\hline & & & & 1690 & 109 & 16.849 \\
\hline & 250 & 4.536 & 1.256 & 1.004 & 470 & $* *$ \\
\hline Indifferent & 250 & 3.596 & 1.091 & & & \\
\hline $\begin{array}{l}\text { Environment } \\
\text { regarding }\end{array}$ & & & & 0.624 & 498 & $\underset{* *}{6.664}$ \\
\hline & 250 & 2.972 & 1.001 & & & \\
\hline Students & 120 & 81.72 & 5.099 & & & \\
\hline & 2120 & 9355 & 5558 & & & $* *$ \\
\hline
\end{tabular}

**-Significant on 0.05 and 0.01 levels of significant.

Table $\mathbf{- 2}$ shows that there is significant difference between the factors contributing to excellence of rural government and rural non-government primary schools of Students enrolment, teacher's qualifications andindifferent environment regarding Students because C.R .value is significant at 0.05 level. Since the mean score of rural government schools is higher, so it is clear that rural government schools had higher in the student's enrolment, teachers qualifications and indifferent environment regarding Students factors.

Table $-\mathbf{2}$ also shows that there is significant difference between the factors contributing to excellence of rural government and rural non- government primary schools of fundamental facilities, teacher student ratio, abstracters besides teaching work, qualitative planning's for students, sports facilities, results, educational environment, language and mathematical development, all round development of students, students attendance, because C.R. value is significant at 0.05 level. Since the mean score of rural non-government school had higher in these factors.

\section{Results}

On the basis of analysis of data the following results were obtained.

1-In the urban government primary school had superior factors of contributing to excellence in students enrolment (blow poverty line) and teachers qualifications.

2-In the urban non-government primary school had superior factors of contributing to excellence infundamental facilities ,teacher student ratio, abstracters besides teaching work, qualitative planning's for students, sports facilities, results, educational environment, language and mathematical development, all round development of students, indifferent environment regarding students, students attendance. 
3-In the rural government primary school had superior factors of contributing to excellence in students enrolment (blow poverty line), teachers qualifications and indifferent environment regarding Students.

4-In the rural non-government primary school had superior factors of contributing to excellence in fundamental facilities, teacher student ratio, abstrackels besides teaching work, qualitative planning's for students, sports facilities, results, educational environment, language and mathematical development, all round development of students, student's attendance.

\section{Educational Importance-}

1-The educational performance can predict about primary schools.

2-In the basis of educational performance, we can predict educational environment.

3-The findings of study can be implement in the school administration and planning's.

4-The Excellency of schools can be maintained by the regular supervision of schools.

5-It can be improved in the level of government institutions by implying of government educational planning by the findings of study.

\section{Scope Of Further Research}

1-The present study can be used widely in national and international level.

2-The present research work is type of quantitative, which can be changed in to qualitative.

3-Present study did complete only the level of primary school, which can be study on intermediate and higher level.

\section{Reference}

[1]. Agarwal, J.C. (1987). Progress of Education in free India: Modern Indian Education \& its Problems, New Delhi, Arya Book Dept.

[2]. Annual ReportBhawan, NishatGanj, Lucknow, (2010-11)

[3]. Buch,M.B.(Editor), Second Survey of Research in Education.P.77-78.

[4]. Desai, D.M. (1953).Universal Compulsory and Free Primary Education in India, Bombay:Indian Institute of Education.

[5]. District ElementryEducation Report card: 2010-11.

[6]. ElementryEducation: State Report Card (U.P.)

[7]. Govt. Publication, (1919).The U.P. Primary Education Act.

[8]. Henry, E. Garret. (1994). Statistics in Psychology and Education, New Delhi:Kalyani Printings. P. $288,289$.

[9]. Indian Ministry of Education. (2010-11). Education in State (Annual), Delhi : Manager Publication.

[10]. Mazumdar, N.N. (2000). A History of Education in Ancient India, Oscar New Delhi, publication.

[11]. McGraw Hills Science \& Technology Dictionary, www. Standard deviation.

[12]. Merrian Webster Dictionary, www. Chi-square downloaded on 08 May.

[13]. Naik, J.P. (1970). Education Commission 1964-66, Rajasthan: ChitraguptPrakashan

[14]. State Govt., Publication, (1926). The U.P. District Board, Primary Education Act.

[15]. Second All India Education Survey, P.10-11. 